\title{
Patients in treatment for chronic low back pain have higher externalised beliefs: a cross-sectional study
}

\section{Pacientes em tratamento da dor lombar crônica têm crenças mais externalizadas: um estudo transversal}

Thiago H. Oliveira', Vinícius C. Oliveira², Rodolfo C. Melo', Rafael M. Melo³, André E. Freitas³, Paulo H. Ferreira²

\begin{abstract}
Background: People with low back pain (LBP) with higher levels of external locus of control have a poorer prognosis and require greater improvements from active interventions in order to consider these interventions worthwhile. Whether locus of control levels differ between participants with LBP in a patient-health provider relationship and those waiting for treatment is unclear. Objective: The aim was to investigate if differences in locus of control exist between participants with non-specific chronic LBP being treated (treatment group) and those waiting treatment (control group). Methods: 100 participants (50 per group) with low back symptoms for at least three months for the current episode of LBP and aged between 18 and 60 years were recruited. Multidimensional health locus of control questionnaire (MHLC) was used to collect their beliefs. Multiple linear regression adjusted for disability was used to compare health locus of control between both groups. Differences were described as mean differences and $95 \%$ confidence intervals. Results: Treatment group scored higher for external locus of control and lower for internal locus of control than control group. Mean differences ( $95 \%$ confidence intervals) were 2.7 points on possible 30-points difference ( 0.5 to 4.8 ) for external locus of control and -2.8 points (-5.4 to -0.1) for internal subscale. Conclusion: Health locus of control was found to be different between treatment and control groups. Participants being treated had higher external locus of control and lower internal locus of control than control group.
\end{abstract}

Keywords: locus of control; low back pain; beliefs; physical therapy.

\section{Resumo}

Contextualização: Pessoas com dor lombar com altos níveis de lócus de controle externo têm piores prognósticos e necessitam de melhores intervenções ativas, uma vez que elas são consideradas mais valiosas. Se os níveis de lócus de controle diferem entre os participantes com dor lombar e aqueles que esperam o tratamento, a relação do atendimento-paciente não está clara. Objetivo: Investigar se existem diferenças no lócus de controle entre os indivíduos com dor lombar crônica em tratamento (grupo tratamento) e aqueles que esperam tratamento (grupo controle). Métodos: Cem participantes (50 por grupo) com sintomas lombares por pelo menos três meses, com um episódio atual de dor lombar e com idades entre 18 e 60 anos foram recrutados. O Questionário Multidimensional de Lócus de Controle da Saúde (MHLC) foi usado para coleta das crenças dos participantes. Realizou-se uma regressão linear múltipla ajustada para incapacidade e para comparação do lócus de controle entre os grupos. As diferenças foram descritas com médias e intervalos de confiança de 95\%. Resultados: O grupo tratamento teve escore mais alto para o lócus de controle externo e mais baixo para o lócus de controle interno quando comparado com o grupo controle. As diferenças médias (intervalo de confiança de $95 \%$ ) foram 2,7 pontos em possível diferença de até 30 pontos $(0,5$ a 4,8) para lócus de controle externo e -2,8 pontos $(-5,4$ a -0,1) para lócus de controle interno. Conclusão: O lócus de controle da saúde encontrado para o grupo tratamento e o controle foi diferente. Os participantes em tratamento tinham um alto lócus de controle externo e um baixo lócus de controle interno quando comparados com os do grupo controle.

Palavras-chave: lócus de controle; lombalgia; crenças; fisioterapia.

Received: 04/20/2011 - Revised: 07/19/2011 - Accepted: 09/29/2011

Continuous Education Institute, Pontifícia Universidade Católica de Minas Gerais (PUCMG), Belo Horizonte, MG, Brazil

${ }^{2}$ Faculty of Health Sciences, University of Sydney, Sydney, Australia

${ }^{3}$ Physical Therapy Department, PUCMG, Belo Horizonte, MG, Brazil

Correspondence to: Thiago Henrique de Oliveira, Avenida General Olimpio Mourão Filho, 166, Apto 103, Bairro Planalto, CEP 31720-200, Belo Horizonte, MG, Brasil, e-mail: thiagooliveirafisio@yahoo.com.br 


\section{Introduction $: \because 8$}

Low back pain (LBP) affects $70-85 \%$ of the population and is the primary cause of disability and job absence in industrialized countries ${ }^{1}$. Prognosis of persistent LBP is not favorable with over $50 \%$ of cases reporting pain after 12 months onset of chronicity ${ }^{2}$, and LBP results in both direct (e.g. costs related to treatment) and indirect costs (e.g. low productivity) to individuals and society ${ }^{3}$. In Australia alone, treatment costs exceed 1 billion Australian dollars a year ${ }^{4}$.

Psychosocial factors such as health locus of control and kinesiophobia have been considered as prognostic determinants in $\mathrm{LBP}^{5-7}$. Health locus of control is defined as the individual's perception of who is responsible for her/his life condition. There are three different types of health locus of control: (i) internal, in which a person believes that he/she is responsible for his/her own condition; (ii) external, in which a person believes that others are responsible for his/her condition; (iii) chance, in which a person believes that his/her condition is determined by luck/chance ${ }^{8}$. People with LBP with higher levels of external locus of control have a poorer prognosis ${ }^{5}$ and require greater improvements from active interventions to consider these interventions worthwhile 9 Often, people with an external health locus of control have difficulties with coping ${ }^{6}$. Perceived coping inefficacy causes distress and may consequently increase pain and decrease function ${ }^{6}$. Cognitive behavior therapy interventions address patients' health locus of control perceptions and coping skills ${ }^{6}$.

While cognitive behavior therapy attempts to address health locus of control perceptions, the potential effects of the patient-health care provider relationship on health locus of control have often not been considered. Health care providers' style and beliefs about the condition has been shown to influence patients' perceptions of locus of control ${ }^{6}$, and might increase external beliefs of patients serving as barriers to improve clinical outcomes. A previous study in the United Kingdon ${ }^{10}$ found that health care providers' beliefs influence their judgments about what treatment interventions are giving to participants with chronic LBP. Health locus of control therefore would be a potential target within clinical management for health care providers and patients ${ }^{6}$.

Patients' beliefs are not often systematically investigated during a patient-health provider relationship ${ }^{6}$ and also not consistent among settings. A previous study ${ }^{8}$ investigated health locus of control in participants with LBP being treated and found higher scores for external locus of control (28.0 and 25.6 for external and internal subscales, respectively). Not consistent with that, another study ${ }^{9}$ investigating health locus of control of participants waiting for treatment found higher scores for internal locus of control (23.7 and 29.0 for external and internal subscales, respectively). These different trend $\mathrm{s}^{8-9}$ reported for health locus of control of participants being treated and those awaiting treatment for LBP imply that: 1) these two groups might have different levels of locus of control; 2) physical therapists' beliefs would predict higher scores of external locus of control. However, no study compared whether locus of control levels differ between participants with LBP in a patient-health provider relationship and those waiting for treatment.

Therefore the aim of this cross-sectional study was to investigate whether there is any difference in health locus of control between patients being treated and those waiting treatment for non-specific chronic LBP.

\section{Methods $: \because$.}

\section{Study design and setting}

This cross-sectional observational study was carried out in a convenience sample of patients attending public physical therapy clinics in Belo Horizonte, MG, Brazil from the end of 2008 to the beginning of 2010 . The project was approved by the Ethics and Research Committee of the Pontifícia Universidade Católica de Minas Gerais (PUCMG), Belo Horizonte, MG, Brazil (CAAE-0051.0.213.000-08) and the participants signed a consent form.

\section{Participants}

Participants of both genders were eligible whether they: 1) presented with symptoms of non-specific LBP; 2) presented with symptom duration of 3 months and over; 3 ) were between 18 and 60 years old; 4) were being treated or awaiting treatment with a physical therapist for LBP. Participants were considered to be treated when they received at least one physical therapy session for the current episode (treatment group). Those participants awaiting treatment were recruited from waiting lists or from first consultations in which treatment had not commenced (control group). Participants in the control group were recruited irrespective of time waiting for treatment.

Patients with fracture, tumor, infectious or inflammatory diseases of the spine and sciatica were excluded ${ }^{11}$.

\section{Health locus of control outcomes and descriptive data}

The Multidimensional Health Locus of Control questionnaire (MHLC) $)^{8}$ was used to assess health locus of control in both the treatment and control groups. MHLC questionnaire has 18 items and is comprised of internal, external and chance subscales with the score for each subscale ranging from 6 to $36^{8}$. Pain and disability were collected using the 0 to 10 visual 
analogue scale ${ }^{12}$ and 0 to 24 Roland Morris disability questionnaire $^{13}$, respectively. These tools are valid and reliable (intraclass correlation coefficients ranging from 0.75 to 0.95$)^{8,12-15}$. Patient demographic information (gender, age, symptom duration, educational level, marital status and employment status) was also collected.

\section{Procedures}

The two groups (treatment and control) completed a descriptive questionnaire, as well as pain and disability questionnaires. The MHLC questionnaire was then completed by participants to investigate health locus of control. Data was collected by the same investigator who was not blinded to group status. Locus of control between the two groups was compared for each individual subscale (internal, external and chance).

\section{Statistical analysis}

Power analyses showed that 45 patients in each group would detect a 3 -point ( $\mathrm{SD}=5$ ) difference, with $80 \%$ power and $\alpha$ of $5 \%$. Sample size calculation was based on previous published data ${ }^{8}$. Considering scores ranging from 6 to 36 for each subscale, the expected difference between groups ranges from 0 to 30 points.

A priori correlation matrix between each health locus of control subscale (i.e. internal, external and chance) and the variables: pain, disability, age, and duration of symptoms identified possible confounders for the differences. These variables were considered because a previous study ${ }^{8}$ reported different trends among samples and an association between the clinical outcome disability and health locus of control. Disability presented a fair correlation ${ }^{16}$ with the external $(\mathrm{r}=0.30 ; \mathrm{p}<0.01)$ and chance $(\mathrm{r}=0.21 ; \mathrm{p}<0.05)$ subscales and thus the between-group differences were adjusted for this predictor.

To compare health locus of control between treatment and control groups, multiple linear regression models were built adjusting for differences in disability, considering normal distribution and $\mathrm{p}<0.05$. This was completed by a blinded statistician. Data was described as mean (95\% confidence intervals). SPSS software (SPSS Inc., Chicago, IL) version 15.0 was used for analyses.

\section{Results $: \because$.}

Characteristics of the sample are presented in Table 1. One hundred participants (50 being treated and 50 waiting treatment), $72 \%$ married and $63 \%$ unemployed were recruited. The mean age was 48.8 years ( 46.6 to 51.1 ) in the treatment group and 47.8 (45.2 to 50.3) in the control group. The majority of participants was female and had completed at least elementary school (over 70\%). Participants reported a long duration of low back pain symptoms (40\% of the treatment group and $36 \%$ of the control group had symptoms duration for 3 years or more). Participants had low levels of pain ( $<3$ out of 10) and moderate levels of disability ( $<17$ out of 24$)$.

In terms of health locus of control, the control group tended to present higher scores for internal subscale (mean: 27.4; 95\%CI: 25.6 to 29.2) than for external (mean: 25.8; 95\%CI: 24.2 to 27.4 ) and chance (mean: 17.9; 95\%CI: 15.3 to 20.5) subscales (Table 2). On the other hand, treatment group had lower scores for internalized (mean: 24.7; 95\%CI: 22.8 to 26.6) and chance beliefs (mean: 20.2; 95\%CI: 18.0 to 22.4 ) than for externalized beliefs (mean: 29.0; 95\%CI: 27.5 to 30.5). Treatment group had significant dominance of externalized beliefs compared to internal locus of control. The difference between external and internal locus of control of the treatment group was 4.3 points favoring external beliefs (95\%CI: 1.9 to 6.7). The same was not observed for the control group (1.4 points difference favoring internal locus of control; 95\%CI: -4.3 to 1.6$)$.

Between-group comparisons for health locus of control found that the treatment group had higher levels of external health locus of control and lower levels of internal health locus of control than the control group (Table 2). Mean difference

Table 1. Sample characteristics ( $n=100)$.

\begin{tabular}{|c|c|c|}
\hline Variable & Being treated $(n=50)$ & Not treated $(n=50)$ \\
\hline Age mean $(95 \% \mathrm{Cl})$ & 48.8 (46.6 to 51.1) & 47.8 (45.2 to 50.3) \\
\hline Gender (\% Female) & $62 \%$ & $72 \%$ \\
\hline \multirow[t]{4}{*}{ Symptom Duration } & $32 \%$ (3 to 12 months) & $26 \%$ (3 to 12 months) \\
\hline & $18 \%$ (13 to 24 months) & $26 \%$ (13 to 24 months) \\
\hline & $10 \%$ ( 25 to 36 months) & $12 \%$ (25 to 36 months) \\
\hline & $40 \%$ (>36 months) & $36 \%$ (>36 months) \\
\hline \multirow[t]{4}{*}{ Education level } & $2 \%$ Illiterate & $2 \%$ Illiterate \\
\hline & $80 \%$ Elementary school & 70\% Elementary school \\
\hline & $16 \%$ High school & 22\% High school \\
\hline & $2 \%$ University degree & 6\% University degree \\
\hline RMDQ mean $(95 \% \mathrm{Cl})$ & 16.4 (15.2 to 17.5$)$ & $14.5(13.2$ to 15.9$)$ \\
\hline VAS mean $(95 \% \mathrm{Cl})$ & 2.9 (2.5 to 3.2 ) & 2.1 (1.7 to 2.5) \\
\hline
\end{tabular}

RMDQ: Roland Morris Disability Questionnaire (range 0 to 24); VAS: Visual Analog Scale of pain (range 0 to 10).

Table 2. Health locus of control comparison between treatment and control groups ( $n=100 ; 50$ treatment/50 control).

\begin{tabular}{|c|c|c|}
\hline MHLC & Mean scores $(95 \% \mathrm{Cl})$ & Between-groups mean \\
\hline subscales & Treatment Control & differences $(95 \% \mathrm{Cl})$ \\
\hline Internal & 24.7 (22.8 to 26.6) 27.4 (25.6 to 29.2) & $-2.8(-5.4 \text { to }-0.1)^{*}$ \\
\hline External & 29.0 (27.5 to 30.5) 25.8 (24.2 to 27.4) & $2.7(0.5 \text { to } 4.8)^{\star}$ \\
\hline Chance & 20.2 (18.0 to 22.4 ) 17.9 (15.3 to 20.5) & $1.6(-1.8$ to 5.0$)$ \\
\hline
\end{tabular}

MHLC: Multidimensional Health Locus of Control questionnaire; Internal subscale (range 6 to 36); External subscale (range 6 to 36); Chance subscale (range 6 to 36); * Statistically significant $(p<0.05)$. 
values (95\% confidence intervals) adjusted for disability were: 2.7 points on possible 30 -point difference ( 0.5 to 4.8 ) for external locus of control and -2.8 points (-5.4 to -0.1$)$ for internal subscale. No between group difference was found for chance subscale $(1.63 ;-1.8$ to 5.0$)$.

\section{Discussion $: \because$.}

The present study found differences in perceived health locus of control between participants being treated for chronic non-specific LBP compared to participants awaiting treatment. Participants in a patient-physical therapist relationship were found to have higher external beliefs and lower internal beliefs than participants awaiting treatment. Although the differences were small ( $<3$ points), these differences are clinically important. As health locus of control is a multidimensional construct comprising three subscales; it is possible that one of these subscales be dominant compared to the others ${ }^{8}$. Our findings revealed that treated participants had dominance of external locus of control (4.3 points difference between external and internal subscales; 95\% CI: 1.9 to 6.7). The same was not true for non-treated participants (1.4 points difference favoring internal subscale; $95 \%$ CI: -4.3 to 1.6). Hence, participants being treated have higher dominance of external beliefs with lower coping skills. This finding is in agreement with the literature ${ }^{6}$.

Our findings show that beliefs of participants being treated are the opposite to guidelines' recommendations for the management of chronic $\mathrm{LBP}^{17,18}$, in which health care providers should empower patients with self-management strategies ${ }^{19}$, giving them a more active role in the treatment process. This study showed that participants with LBP being treated in rehabilitation settings have higher external locus of control beliefs and are therefore more dependent on the health care system, as they prefer passive treatment for the low back symptoms. This passive participation may increase costs of treatment. LBP is a recurrent condition ${ }^{2}$ and most passive treatments have only small immediate effects ${ }^{20}(<20$ points improvement on 0-100 scale) with no long-term effect. On the other hand, active treatments empower participation of patients and have been shown to have satisfactory effects on pain and disability in $\mathrm{LBP}^{21,22}$. While active treatments such as exercises and behavioral therapy ${ }^{21,22}$ have similar effects as passive treatments, these active interventions empower patients' participation and decrease costs in persistent episodes ${ }^{21}$. This is desirable for LBP which is considered a chronic condition ${ }^{2}$.

Previous evidence ${ }^{10}$ has demonstrated that health care providers are aware of LBP guideline recommendations, even though their beliefs influence decision-making during a patient-health care provider relationship. It supports the hypothesis that physical therapists can influence patients' beliefs ${ }^{6}$, and would explain the opposite results of our findings and what the LBP guidelines recommended ${ }^{17,18}$. Our findings are in agreement with previous studies reporting higher trends for external health locus of control of patients being treated (28.0 and 25.6 for external and internal subscales, respectively) ${ }^{8}$ and higher internalized beliefs of those not being treated (23.7 and 29.0 for external and internal subscales, respectively) 9 .

\section{Limitations of this study}

This was the first study investigating health locus of control differences between participants with LBP being treated and those awaiting treatment adjusting for possible confounders (i.e. disability). In addition, outcome measures were assessed by valid and reliable tools. Nevertheless, results could be affected by how group allocation was determined and the outcome measures used. Blinding of participants seeking care for LBP that are awaiting treatment or being treated by physical therapists was not possible and the outcome assessor was not blinded. Additionally, the duration of time spent waiting for treatment (control group) and type and duration (treatment group) may be possible confounders. Although the present study did not control for these factors, further investigation should include them. Due to limitation of cross-sectional designs, future longitudinal studies should investigate physical therapists beliefs as predictors for patients' external beliefs and their impact on clinical outcomes.

\section{Conclusions $: \because 8$}

Health locus of control was found to be different between people with LBP who were receiving treatment and those who were waiting for their treatment to commence. People who were receiving treatment for their LBP had higher external locus of control and lower internal locus of control than people awaiting treatment. Immediate implication of higher external beliefs of participants being treated is that they expect higher effects from active interventions such as exercises ${ }^{9}$. Long-term effects would be lower coping skills for recurrent episodes and higher costs. Further studies should investigate whether physical therapists beliefs during a patient-health care provider relationship predict patients' beliefs and clinical outcomes. If so, strategies to improve physical therapists decision-making should be considered in primary health care. 


\section{References $: \because$.}

1. Silva MC, Fassa AG, Valle NCJ. Dor lombar crônica em uma população adulta do sul do Brasil: prevalência e fatores associados. Cad Saúde Pública. 2004;20(2):377-85

2. Costa Lda C, Maher CG, McAuley JH, Hancock MJ, Herbert RD, Refshauge KM, et al. Prognosis for patients with chronic low back pain: inception cohort study. BMJ. 2009;339:b3829.

3. Kerns RD, Jacob MC. Psychological aspects of back pain. Baillieres Clin Rheumatol. 1993;7(2):337-56

4. Walker BF, Muller R, Grant WD. Low back pain in Australian adults: the economic burden. Asia Pac J Public Health. 2003;15(2):79-87.

5. Linton SJ. A review of psychological risk factors in back and neck pain. Spine (Phila Pa 1976). 2000;25(9):1148-56

6. Main CJ, Foster N, Buchbinder R. How important are back pain beliefs and expectations for satisfactory recovery from back pain? Best Pract Res Clin Rheumatol. 2010;24(2):205-17.

7. Waddell G. Biopsychosocial analysis of low back pain. Baillieres Clin Rheumatol. 1992;6(3):523-57.

8. Oliveira VC, Furiati T, Sakamoto A, Ferreira P, Ferreira M, Maher C. Health locus of control questionnaire for patients with chronic low back pain: psychometric properties of the BrazilianPortuguese version. Physiother Res Int. 2008;13(1):42-52.

9. Oliveira VC, Ferreira PH, Ferreira ML, Tiburcio L, Pinto RZ, Oliveira W, et al. People with low back pain who have externalised beliefs need to see greater improvements in symptoms to consider exercises worthwhile: an observational study. Aust $\mathrm{J}$ Physiother. 2009:55(4):271-5.

10. Corbett M, Foster N, Ong BN. GP attitudes and self-reported behaviour in primary care consultations for low back pain. Fam Pract. 2009;26(5):359-64.

11. Henschke N, Maher CG, Refshauge KM, Herbert RD, Cumming RG, Bleasel J, et al. Prevalence of and screening for serious spinal pathology in patients presenting to primary care settings with acute low back pain. Arthritis Rheum. 2009:60(10):3072-80.
12. Scrimshaw SV, Maher C. Responsiveness of visual analogue and McGill pain scale measures. J Manipulative Physiol Ther. 2001;24(8):501-4.

13. Nusbaum L, Natour J, Ferraz MB, Goldenberg J. Translation, adaptation and validation of the Roland-Morris questionnaire - Brazil Roland-Morris. Braz J Med Biol Res. 2001;34(2):203-10.

14. Costa LO, Maher CG, Latimer J. Self-report outcome measures for low back pain: searching for international cross-cultural adaptations. Spine (Phila Pa 1976). 2007;32(9):1028-37.

15. Costa LO, Maher CG, Latimer J, Ferreira PH, Pozzi GC, Ribeiro RN. Psychometric characteristics of the Brazilian-Portuguese versions of the Functional Rating Index and the Roland Morris Disability Questionnaire. Spine (Phila Pa 1976). 2007;32(17):1902-7.

16. Landis JR, Koch GG. The measurement of observer agreement for categorical data. Biometrics 1977;33(1):159-74.

17. Bekkering GE, Hendriks HJM, Koes BW, Oostendorp RAB, Ostelo RWJG, Thomassen JMC, et al Dutch Physiotherapy Guidelines for Low Back Pain. Physiotherapy. 2003;89(2):82-96.

18. Chou R, Qaseem A, Snow V, Casey D, Cross JTJr, Shekelle P, et al. Diagnosis and treatment of low back pain: a joint clinical practice guideline from the American College of Physicians and the American Pain Society. Ann Intern Med. 2007;147(7):478-91.

19. Lorig KR, Holman H. Self-management education: history, definition, outcomes, and mechanisms Ann Behav Med. 2003;26(1):1-7.

20. Machado LA, Kamper SJ, Herbert RD, Maher CG, McAuley JH. Analgesic effects of treatments for non-specific low back pain: a meta-analysis of placebo-controlled randomized trials. Rheumatology (0xford). 2009;48(5):520-7.

21. Lamb SE, Lall R, Hansen Z, Castelnuovo E, Withers EJ, Nichols V, et al. A multicentred randomised controlled trial of a primary care-based cognitive behavioural programme for low back pain. The Back Skills Training (BeST) trial. Health Technol Assess. 2010;14(41):1-253, iii-iv.

22. Macedo LG, Smeets RJ, Maher CG, Latimer J, McAuley JH. Graded activity and graded exposure for persistent nonspecific low back pain: a systematic review. Phys Ther. 2010:90(6):860-79. 